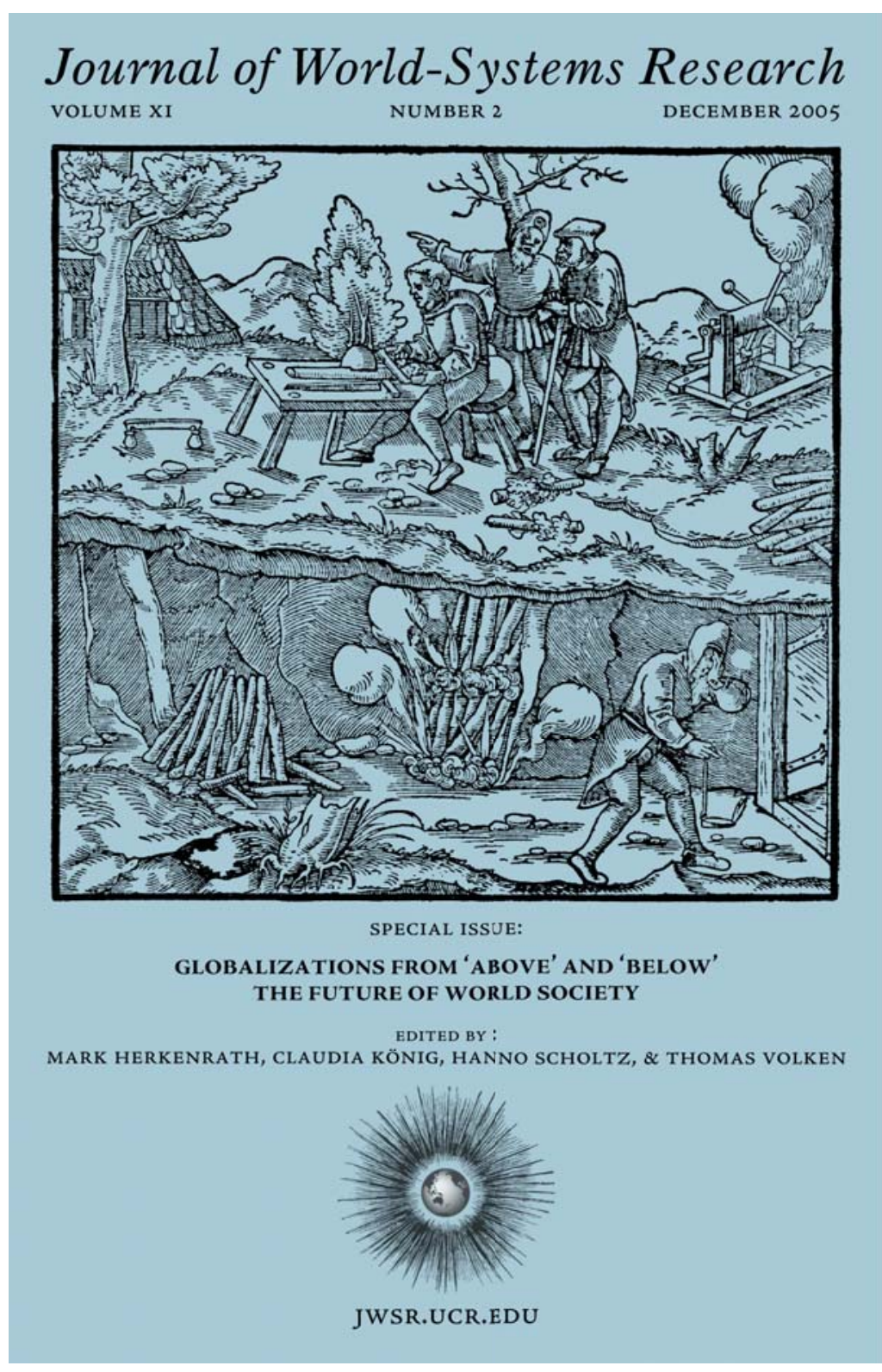

ABSTRACT:

A revisit, and an extension, of the paper "From Leadership to Organization: The Evolution of Global Politics," originally presented at the University of $\mathrm{Zu}$ rich in 1993. Three long-term processes

\section{Long-Term Trends in World Politics}

George Modelski

\section{INTRODUCTION}

The point of departure of this discussion is the paper entitled "From Leadership to Organization: The Evolution of Global Politics," first read in Zurich in 1993, and in Bielefeld in 1994, at the World Congress of the International Sociological Association, published in this journal in 1995, and finally, in hardcopy in 1999, in a volume edited by Volker Bornschier and Christopher Chase-Dunn. I mention these circumstances for two reasons. It means that I presume at least some general acquaintance with the content of its arguments but more importantly I wish to point to the lapse of time, more than a decade since its writing, and that makes it worthwhile to pose the question: are its arguments still valid and how were they affected by the passage of time and the eventful course of world politics since the early ig9os.

In that paper (subsequently referred to as "Leadership"), I examined in some detail the make-up of two important processes: the well-known long cycle of global politics, a.k.a. the hegemonic cycle, or the rise and decline of world powers; and the less well-recognized evolution of global politics, a related institutional process at a higher level of organization that is in effect one of "political globalization." I presented the thesis, and the prediction, that the working of long cycles activates, at a higher level of organization, the evolution of global politics, such that the political system at that level moves from a condition in which the chief institution organizing it is global leadership, to "global organization," one of a more fully institutionalized form of governance.

\section{George Modelski \\ Department of Political Science \\ University of Washington \\ 101 Gowen Hall \\ Seattle, WA 98195-3530 \\ modelski@u.washington.edu \\ http://faculty.washington.edu/modelski/index.html}

JOURNAL OF WORLD-SYSTEMS RESEARCH, XI, 2, DECEMBER 2005, I95-206 Special Issue: Globalizations from 'Above' and 'Below' - The Future of World Society http://jwsr.ucr.edu/

ISSN $1076-156 \mathrm{x}$

(C) 2005 George Modelski 
The reference here was not to trends-understood as "prevailing tendency, drift, or general line of direction or movement" that can be described or perhaps extrapolated-but rather to processes understood as sequences of events that can be explained and whose overall outlines are capable of being predicted. Our representation of these processes amounts to constructing a calendar of global politics. Calendars (viewed as organization in time) are, of course, social constructions that were among the earliest achievements of civilization, but also are vital parts of everyday lives. But calendars are not just human handiworks for they model or reflect the working of natural processes. By building calendars we seek to accommodate ourselves to the forces of nature but we also try to harness them to our purposes.

On this occasion, I examine, and update when needed, two processes, starting with globalization, and followed by the long cycle, and place them in the context of the emergence of the world system. For each process we ask: where in its trajectory is global politics located at the present time, and what might be the prognosis for the future, up to a century ahead? We shall then review the current status of the main prediction. In conclusion I pose a more general question: does the "cascade" of processes subsumed under world system evolution represent a category of phenomena subject to general laws that chart the overall direction of the "future of world society"?

\section{eVOlution of global politics as political globalization}

Let us reaffirm the basic argument of "Leadership," namely that the processes we are discussing are evolutionary. By that we mean that that they invoke structural change at the global level, and that they are explicable with the help of evolutionary theory. From what we know of the past millennium we can tell that such change has been significant, and that an evolutionary explanation makes sense. What evolves is global-level organization that is a condition of world society, and it evolves via the mechanism of evolutionary learning.

The evolution of global politics is a higher-order learning process than the long (or hegemonic) cycle (to be reviewed shortly). It is a process of globalization $^{1}$ creative of political institutions of world-wide scope in periods spanning half-a-millennium. It is one of political globalization because it accounts for the

1. I do not regard "globalization" as "the natural doctrine of global hegemony" (as Brzezinski [2004: 143] would label it), because political globalization in fact accounts for the transition from the period of "global leadership" to that of "global organization." But it is, as he also writes,"a phenomenon having a deeper moral dimension" (ibid: 219).
Table 1 - A Calendar of Global Politics: 1000 to $3000^{*}$

\begin{tabular}{|c|c|c|c|}
\hline $\begin{array}{l}\text { Learning Algorithm } \\
\text { (g-c-t-r) at two levels }\end{array}$ & $\begin{array}{l}\text { Periods (\& Phases) } \\
\text { of Global Political } \\
\text { Evolution }\end{array}$ & $\begin{array}{l}\text { Characteristic } \\
\text { Global Institution }\end{array}$ & Major Interactors \\
\hline \multirow[t]{3}{*}{1 (g) } & Preparatory & World Empire (Failed) & \\
\hline & & $930-$ & \\
\hline & & $1190-$ & Mongol federation \\
\hline 2 (c) & Nucleus Formation & Global Leadership & \\
\hline $\mathrm{g}$ & Information & 1430 - discoveries & Portugal, Spain \\
\hline$c$ & Integration & 1540 - Calvinist international & Dutch Republic, Spain \\
\hline $\mathrm{t}$ & Political formation & 1640 - Europe's Balance & Britain, France \\
\hline$r$ & Economic innovation & 1740 - industrial revolution & Britain, France \\
\hline $3(t)$ & Selection & Global Organization & \\
\hline g & Information & 1850 - IT revolution & USA, Britain, Germany \\
\hline$c$ & Integration & 1975 - democratic transition & USA, China, EU, UN \\
\hline $\mathrm{t}$ & Political formation & 2080 - global organization & \\
\hline$r$ & Economic organization & $2175-$ & \\
\hline $4(r)$ & Amplification & Stability & \\
\hline
\end{tabular}

* What is being tested, and selected, in each period of global political evolution is the institutional set-up to govern global interactions. Upon the failure of the Mongol project of world empire, the second period tests an alternative form of organization (global leadership, whose elements include navies, bases, and alliances) against the designs of a number of aspirants for imperial rule. With Britain, it hits upon an acceptable middle solution: the informal role of global leadership, and not empire (as some have argued recently). By the 20th century, the United States steps into the now established role but at a time and in conditions that indicated that movement toward new forms of global organization was already underway.

The table shows each period of global political evolution as an instance of the working of the learning algorithm (that is, of the enhanced Lewontin-Campbell heuristic: g-c-t-r: generate-cooperate-test-regenerate, Modelski 2004), a sequence of four iterations of that algorithm at the global institutional level. In turn, each such period contains (in a nested, self-similar process) four long long cycles, each representing one phase of that same algorithm.

formation of political structures that weave together several strands of relationships of world-wide range. Where earlier, in the classical era, political interaction was mainly either local or regional, at about the year rooo new interactors began to emerge at the planetary level, and started to activate a process of global political evolution. Table I presents a calendar for four periods of that process (spanning two millennia) but highlights in particular institutional developments in the second and third periods.

Table I shows the first period of global political evolution as preparatory, that is laying down the technical preconditions of global order, in part by defeat- 
ing the project of the Mongol world empire. The second created the nucleus of global organization by defeating even more imperial challenges ${ }^{2}$ and by means of the institution of global leadership. The two British cycles represented the mature form of that organizational structure as it moved from selection, to amplification. The third period, that we entered as early as mid-I $9^{\text {th }}$ century, is that of global organization. If the first period was one of no (or failed) organization, and the second one of minimal organization, the third is one of selecting an adequate structure of organization (to be completed in the fourth). By adequate structure I mean one that has the capacity to cope decisively with the problem of human survival, especially in respect of nuclear and environmental threats.

Where in this scheme do we stand at the beginning of the $2 \mathrm{I}^{\text {st }}$ century? The third period that we have already entered is certainly critical. The third period (selection and formation of global organization) is currently in the second of its preparatory phases (in the $-c-$ phase of cooperation and integration) of this major institutional innovation that, on this analysis, will bring significant institutional change in the next, $-\mathrm{g}$ - phase of that process, a century from now. That (third) period will not be completed for two-three centuries. But we also recall that each such period consists of four phases, and in this instance, of four long cycles, and would extend over a half-millennium. Since about 1975 we have been in the second (integrative, community-building) phase of that third period, and that phase might extend to the last quarter of the century. That means that this, current, phase has several more decades to go.

The prognosis is this: the global political system has been, since 1850, in transition to global organization, and that means that the US cycle has been no mere repetition of the British experience, but was shaped by that fact. We are now, at the start of the $2 \mathrm{I}^{\text {st }}$ century, in the second, coalitional, phase of that of transition. That phase will not be completed until mid-2 ${ }^{\text {st }}$ century, and will determine the coalition that will shape future global organization: will it be the global democratic community, or a system of "multipolarity"?

One implication of the transition concerns the concept of power. In the period of global leadership, global power could be indexed by the ability of a nation-state to deploy forces of global reach, principally naval, and air. As political globalization consolidates, another, if related, power index grows in

2. In "Leadership" (Modelski 1999: 32) the defining problem of the second period was "Balance of Power in Europe after 1713." The defeat of imperial challengers was indeed a primary global problem but it was "global leadership" that was the institutional innovation of that period. significance: the capacity to sway decision-making bodies, both executive and parliamentary devices of party organization. Current examples include the role of the United Nations Security Council, and the General Assembly. As global forces gain strength, toward the next century, the control of global organization, e.g. via majority voting blocs, would become the condition of organizational leadership. A democratic community might be one such case. Parallel changes would affect the world market for protection.

\section{LONG CYCLES OF GLOBAL POLITICS}

The concepts of "rise and decline of world powers," or the long (or "hegemonic") cycle are now familiar to students of this subject, and they highlight principally the role of leading states, and the imperial challengers that squared off against them. That is, it is an agent-based process that is in fact subsidiary to political globalization. That of long cycles in particular goes further and includes the notion that what we are studying is a four-phased learning process (and therefore one that is structurally identical, self-similar but on reduced scale, to the two other processes we are considering). It is a basic feature of the four-phased learning cycle that the first two of its phases are preparatory in character, and that real change sets in its third, the selection phase. As we have already seen, the phasing makes it possible to establish the location in time, of the system we are analyzing. We might also add, that this learning process (as we argue) assumes the "global leadership" (or "hegemonic") form only in the second period of global political evolution that is in only one part of its trajectory.

At the time of writing "Leadership," the early I99os, the global political system was in the phase of Agenda-setting (1973-2000). At the present time, in the first decade of the $2 \mathrm{I}^{\text {st }}$ century, it has moved into the phase of coalitionbuilding (2000-2026). Both of these are the preparatory phases of the new cycle, LCIO, even while the United States is still filling its role of leadership. On the analogy with a four-year electoral cycle, global leadership is moving into the lame duck season, anticipating an approaching (s)electoral test.

\section{A COMMUNITY OF DEMOCRACIES}

In "Leadership" (p.I8) I predicted flatly that "by 2000, the global democratic community might be expected to become the focus of coalition-building."

3. One of its recommendations (that the Foreign Minister of France was the only one to vote against) was the formation of "democracy caucuses" at the United Nations. 
Indeed, in that year a "Community of Democracies" was organized at an international meeting of ministers from over roo countries that met in Warsaw. ${ }^{3} \mathrm{~A}$ second such conference was held in Seoul in 2002, and a third is planned for Santiago, Chile in 2005. Maybe a more precise way of expressing that prediction should have taken the form "after 2000..." because the Community is not yet "the focus" of international organization; the movement is slow but the idea of global democracy is certainly in the air even though its ultimate shape is as yet uncertain.

The main alternative vision has, since the collapse of the Soviet bloc, been that of "multipolarity." That is a notion advocated in France, but also one that at various times was also espoused by leaders in i.a. Moscow and Beijing. Lacking in detail, it seems to hark back to late-19 $9^{\text {th }}$ century conceptions of balance of powers, a time when the European system of states was beginning to line up into two opposing camps that ultimately faced off in World Wars I and II. At bottom, it is a counter to "unipolarity" that some see to be emerging on the basis of United States predominance. The default (but hardly promising) position is that of "international community" on whose behalf action is taken by a "coalition of the willing," within or without the United Nations.

All in all, we are still early in the coalition-building phase, with some two more decades to go, and much is yet to happen. But it is also a hallmark of this phase that democracies now hold (for the first time ever) a majority position in the world, ${ }^{4}$ a condition that favors cooperation and makes war among a large portion of the world less likely. That is why the odds for the long term do lie on the side of a democratic community. In Table $\mathrm{I}$, we can discern a growth of a democratic "lineage" that runs through the second, and plausibly, through, the third and fourth eras of the process and that is closely linked to democratization (the world-wide spread of democratic practices).

\section{IMPERIA DETOUR?}

A rounded conception of the two preparatory phases of a period of global leadership would also draw attention to the "lame duck" feature of that season of world politics. At a time when the "sitting" world power is past the phase of executing its primary agenda, that whose execution placed it in office in the first place, tension and uncertainty arise, prompting projects that amount to an "imperial detour." A case in point, and a significant current example, is the Iraq

4. In 2000, 57.I percent of the world's population lived in democracies (Modelski and Perry 2002: 365). war of 2003. For in the period of transition from global leadership, world politics is poised uneasily between "empire" as the historically familiar form of largescale organization, and "global organization" as the new, promising but as yet untested way of the future. In fact, the major conflicts of that period involve the defense of clusters of autonomous states from the designs of imperial powers. The incumbents of the (only lightly institutionalized) office of global leadership are torn between the future promises of a global organization and the "traditional" pull of empire. Their primary agenda will have tackled the then urgent global problems (that included the defeat of imperial challengers) but as these problems have been met, they slip into "traditional" patterns and yield to imperial temptation.

Britain, past its second cycle, offers an illuminating example. ${ }^{5}$ In 1899 a Conservative government authorized a war against two small Boer Republics in Southern Africa, experienced early reverses, and sustained guerilla insurgency, challenges that were met by the deployment of large forces ${ }^{6}$ and at great cost to its international standing. ${ }^{7}$ Transvaal and the Orange Free State were annexed in 1902 but as early as 1910, under a Liberal government in London, all of South Africa became self-governing, soon to be led by the leaders of the Boer commandos, Botha and Smuts. English historian G.M. Trevelyan summed up the lessons of that war as follows: "It put an end to the somewhat boastful type of Imperialism, which dominated the last years of the Nineteenth century, a spirit which...would have made trouble in the dangerous epoch now approaching."

The Boer war was hardly an isolated incident in the aftermath of Britain's second (learning) cycle (1740-1850). By 1858 the British government was ruling

5. Similar patterns can be observed in the "lame duck" phases in each of the cycles of global leadership: following the first British cycle of 1640-I740, (the war of American Independence I776-1783), the Dutch cycle of 1540-1640 (the Dutch East India Company launching the conquest of Java after 1650 , to become a territorial power); and the Portuguese cycle of I430-I540 (expedition in Morocco I578).

6. The British forces of 450,000 included contingents from Australia, India, New Zealand and Canada; they suffered 22,000 fatalities.

7. Max Beloff (1970: 75) minimizes the original pretexts for that war, and stresses the determination of Alfred Milner (high commissioner for South Africa) and Joseph Chamberlain (Colonial Secretary) to "assume political control of the Transvaal, so as to prevent trouble elsewhere in South Africa and demonstrate the solidity and strength of the Empire." Both Milner and Chamberlain were part of the "imperialist milieu" in Britain at the turn to the $20^{\text {th }}$ century (Kennedy 2004: I8). 
over the entire Indian subcontinent, and in 1877 Queen Victoria was declared Empress of India. The prevailing foreign policy orientation of Conservative governments under Lord Salisbury was one of free hand and avoidance of alliances. But the war revealed the dangers of such "splendid isolation"; it was followed, in short order, by the Anglo-Japanese alliance (1902), the Entente Cordiale (1904), and the Anglo-Russian agreement (1907).

But the war is worth recalling for another reason: it triggered a stream of writing denouncing "economic imperialism." As the hostilities were coming to a close, in 1902, J.A. Hobson published Imperialism: A Study, proposing an interpretation that was in effect a generalization of that war's experience: war driven by special interests, and large firms, (Rhodes') seeking new markets and supplies (gold, diamonds), but not benefiting the national interest. V. I. Lenin picked up, and enlarged on these themes in his influential 1916 volume (written in Zurich). But his prediction, of a collapse of capitalism in its "highest stage," proved wrong. The South African experience suggests that the "imperial detour" is a structural problem of the "lame duck" phases of the "global leadership" period of global political evolution that is troublesome but not beyond remedy.

\section{MACRODECISION}

Looking further ahead we come to the next phase of the current long cycle, its "selection" phase of Macrodecision (2026-2050). In the four earlier cycles this was the phase that generated global wars, and as their product, new leadership. In "Leadership" (p. I8) I argued that "there is no reason why in the future this process could not assume a different form, coming to a decision without resort to large-scale violence... such substitutes can in fact emerge from within the democratic community."

We might consider two scenarios: in the first, we see a cohesive global democratic community, comprising not only the majority of the world's population, but also the preponderance of its military, economic, and technological resources, and a majority "party" within the United Nations. This arrangement might present such unassailable strength that a direct military challenge would obviously be unproductive, if not utterly destructive but it calls for bold structural innovation in the institution of global leadership.

The second, multipolar, scenario, is more conventional but allows for the possibility of alliances between the several poles of that system, and within the United Nations, hence also between democratic and non-democratic states. This alternative might reduce the chances of deep division, but courts the dangers of large-scale military confrontation.
So much for the form a contested macrodecision might take two-three decades from now. As for its substance, we have argued elsewhere that at the present time the probabilities favor the re-selection of the United States to a second term of global leadership.

\section{EMERGENCE OF THE WORLD SYSTEM}

The social organization of humans today is manifestly more elaboratemore complex - than it was 5000 years ago (cities, writing, states, great communities, world trade, etc.). To explain this we postulate a cascade of evolutionary processes (Devezas and Modelski 2003) that includes political globalization and the long cycle. The highest of these is the world system process setting the major tasks in each phase of the (world-scale, species-wide) four-phase learning process $^{8}$ and describing the world system (or world society) that still is a "workin-progress."

At this level, the four phases of that process appear as the familiar eras of world history: ancient, classical, modern and (presumptively) post-modern. But viewed as successive elements of a learning algorithm they become part of a generalized learning process; they each assume a character all their own, defined by a major theme (characteristic of that phase of the learning process): ancient, by creating the learning infrastructure; classical, by socio-religious organization; and modern, by the problem of collective organization on a planetary scale (for empirical tests, see i.a. Devezas and Modelski 2003). The emergence of the world system (or world society) might then be seen as if programmed by a fourphased learning algorithm represented in Figure I: Logistic curve for the world system process.

Where are we now, and what is the prognosis? Figure I shows, at Iooo, the flex-point that tips the emerging system toward the selection phase of collective (political) organization. Our present position, in about 2000, lies at the midphase of that phase. That position also indicates that as much as 80 per cent of that great learning project (of populating the planet, and organizing for living

8. We derive the following principles from our theoretical analysis (Modelski 2004): the human species is capable of self-organization at multiple levels (including also at the species-hierarchical level), over time in a cascade of (autocatalytic) learning algorithms (simple rules in the form of the enhanced Lewontin-Campbell heuristic), and in such a manner as to create replicators, and constitute a lineage, assuring continuity. 
Figure 1 - The Four-Phased Millennial Learning Process of the World System*

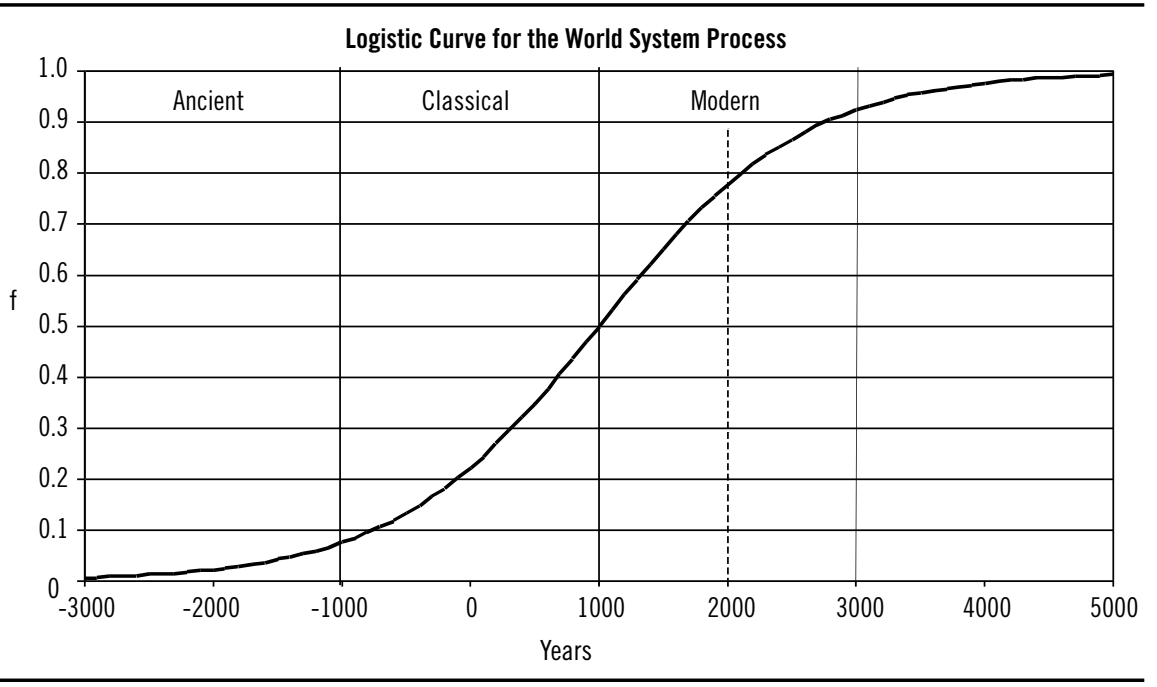

* Curve for the world system process given by equation (1), for $n=8(g=256)$ evidencing the major phases of world history: ancient classical and modern. We are now well into the third phase, the modern era, reaching 80 percent of completion of the whole process after Devezas and Modelski 2003:856.

(1) $f=\{1+\exp [-\partial / n(t-t o)]\}$

$f$ is the fraction of the process completed at time $t$

$\mathrm{g}$ is the number of generations

together) might now be complete, the reason being that most of the steep part of the learning curve is now behind us. That means that the bulk of the construction of the world system may now be in hand. No revolutionary changes loom ahead even if the work of putting the finishing touches on this great project still lies ahead.

In summary: Guided by the injunction: "to know the future, know the past," this review of long-term trends in world politics" yields the following findings:

The main prediction (in "Leadership") of a transition from the institution of global leadership to a form of global organization is holding up well. But such an advance might not take conclusive form for another century.

The foundation for such an advance is likely to be the emerging global democratic community. The "imperial detour" is a structural feature of the institution of "global leadership" that is unlikely to change the long-term trend just outlined. The world system as a whole is well underway in the modern era of collective organization for world society.

This account of trends in political globalization is of course only part of what evolutionary analysis can contribute to charting future tendencies. Other processes that yield insights include the course of the current K-wave of economic innovation (peaking in the mid-2020s), the trajectory of world democratization (reaching 90 percent saturation by the end of the century), and related to it, the processes of equalization (that also characterized earlier eras of the world system).

\section{SOME GENERAL CONSIDERATIONS}

Implicit in this discussion has been the view that world politics holds important elements of order that are not so well hidden as to be unknowable, and that might lend themselves to systematic analysis. The calendar that we have presented suggests the working of an evolutionary "clock" that in turn raises the question whether such analysis implicates general principles or universal laws.

Nineteenth century "philosophies of history" proposed a number of schemes that elucidated laws of history or society, and prominent names that come to mind include Comte, Spencer, and Marx. Their schemes generated much attention and much political capital but lost traction in the course of the $2 \mathrm{O}^{\text {th }}$ century. The expansion of the social sciences - which they promoted-and the increase in historical understanding that has occurred made them appear dated, perhaps lacking in sophistication. But it could not be excluded that they also contained important insights when they portrayed large-scale processes as shaping portions of the human experience.

A relevant analogy might be derived from the physical sciences. Newton's laws of gravity have been, for centuries, prominent metaphors if not models of social organization. But the fabric of the cosmos might be a set of phenomena made accessible by two distinct bodies of theory (so far unreconciled). These are general relativity, the science of the large that elaborates on gravity, and quantum mechanics, that deals with the realm of the small. While general relativity proposes general laws that govern the universe, quantum mechanics is the realm of uncertainty, and probability.

Might it be that the social sciences-that attempt to unravel the patterns in the fabric of the social cosmos-might be subject to the same condition? Could it be that the evolutionary study of globalization and world system emergence will reveal "clocks" that time (or programs that encode) the-possibly-simple rules that animate these structural processes? But such rules would also be unsuitable if relied upon to deal with the complexities of individual decisionmaking or collective behavior.

In $20^{\text {th }}$ century historiography, the debate has been between those who favor the search for covering laws, in the Humean-Hempel mode, and others who disdain general principles and regard historical writing as the reenactment 
of past experience in the verstehen mode. Similar arguments have, in this generation, pervaded the social sciences. Could it be that both sides of that argument have merit, depending on what is being investigated? And if we want to penetrate the hidden order of large-scale organization of humanity and the future of world society, we cannot neglect the search for general, and elegant and preferably non-complex, rules that might govern it.

\section{REFERENCES}

Beloff, Max. 1970. Imperial Sunset, Volume I. New York: Knopf.

Brzezinski, Zbigniew. 2004. The Choice: Global Domination or Global Leadership. New York: Basic Books.

Devezas, Tessaleno, and George Modelski. 2003. "Power Law Behavior and World System Evolution: A Millennial Learning Process." Technological Forecasting and Social Change 70: 819-59

Kennedy, Paul. 2004. “Mission Impossible?” New York Review of Books 5I (June I0): I6-I9.

Modelski, George. 1999. "From Leadership to Organization: The Evolution of Global Politics." In The Future of Global Conflict, edited by Volker Bornschier and Christopher Chase-Dunn. London: Sage Studies in International Sociology. . 2000. "World System Evolution." In World System History: The Social Science of Long-Term Change, edited by Robert Denemark et al.. New York: Routledge.

. 2004. "Beyond Analogy." The Evolutionary World Politics Home Page: http://faculty.washington.edu/modelski/index.html.

Modelski, George, and Perry Gardner. 2002. "'Democratization in Long Perspective' Revisited." Technological Forecasting and Social Change 69: 359-76.

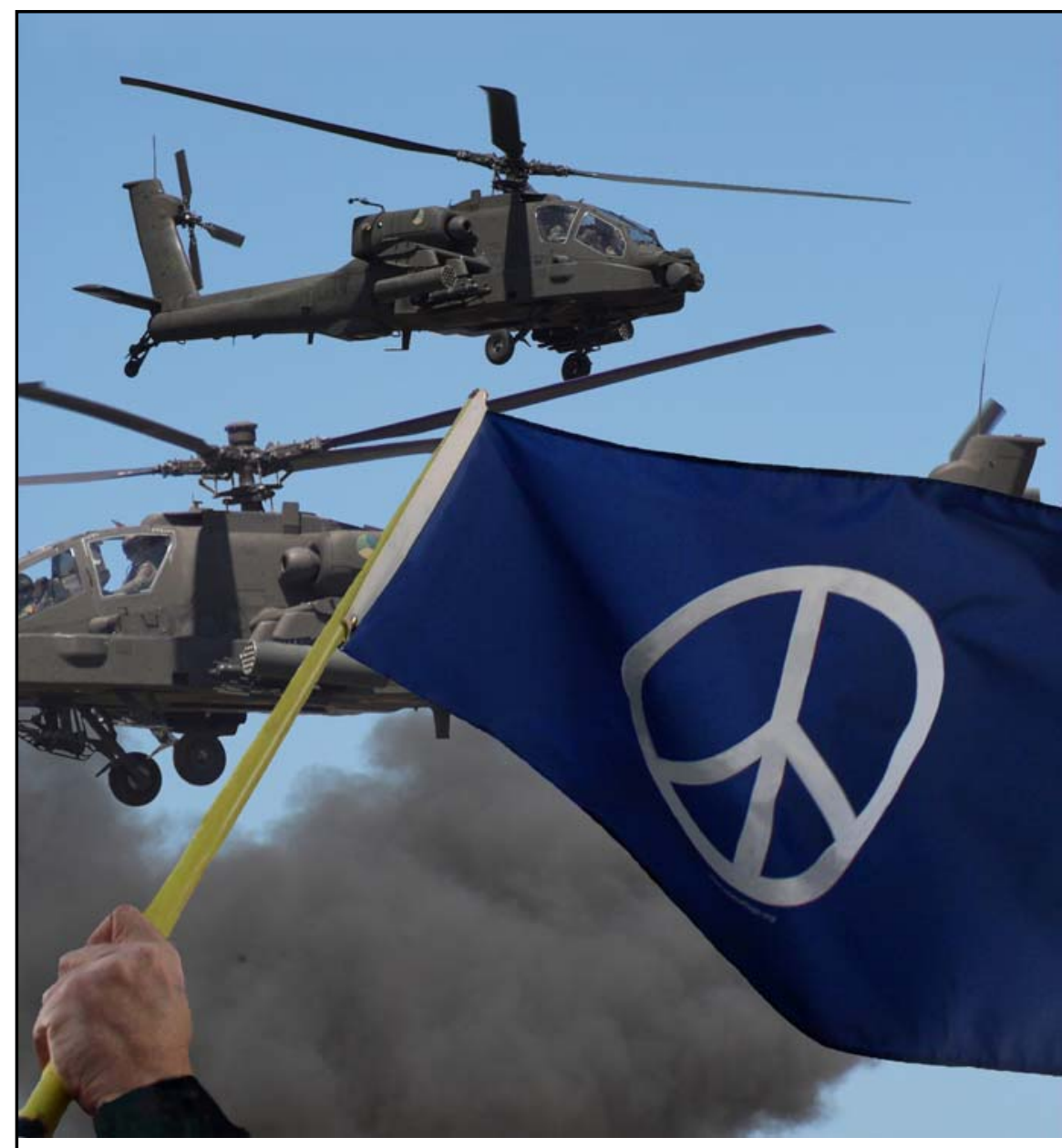

\section{They've got Attack Helicopters We've got Mugs \\ (and over I2,000 unique visits a month)}

JWSR needs your financial contributions now more than ever. Proceeds are used for future publication of the Journal of WorldSystems Research. Please help us by purchasing a JWSR Mug or making a donation today! 